\title{
The reproductive performance of South African indigenous goats grazing Leucaena leucocephala pasture and natural veld during gestation.
}

\author{
A. A. Akingbade ${ }^{1}$, I. V. Nsahlai ${ }^{1}$, C. D. Morris $^{2}$ and M. L. K. Bonsi ${ }^{1}$ \\ ${ }^{1}$ Animal and Poultry Science, School of Agricultural Sciences and Agribusiness, University of Natal, P Bag X 01, Scottsville, \\ 3209, South Africa; ${ }^{2}$ Range and Forage Institute, ARC, University of Natal, P Bag X01, Scottsville, 3209, South Africa
}

\section{Introduction}

The widely distributed South African indigenous goat (SAIG) is reared under extensive systems (Duvel \& Afful, 1994) characterised by low production rates resulting from nutritional constraints. Leucaena species grow well in the absence of nitrogenous fertilizer and are rich in protein $(14-30 \% \mathrm{CP}$ ) and minerals ( Nsahlai et al., 1994). Incorporation of Leucaena cultivation into these farming systems will not only improve soil fertility but alleviate nutritional constraints for ruminants. Substantial benefits were reported on intake, digestibility and growth of ruminants fed Leucaena ( Morris \& du Toit, 1998) but there were no reports on the forage carry-over effects.

\section{Materials and Methods}

Twenty DHP-inoculated SAIG that had previously grazed on Leucaena leucocephala/grass pasture or natural veld during gestation were used for the study. During the study, they were fed on concentrates containing 0 or $10 \%$ molasses during lactation. Doe and kid weight were recorded weekly for 10 weeks. Return to oestrus was determined using vasectomised bucks. Milk yields were determined weekly using the weigh-suckle-weigh and hand milking methods. The proximate composition of the diet and milk protein content was analysed according to AOAC (1984) methods. The experimental design was 2(gestation diets) x 2(lactation diets) factorial. Doe and kid weights and milk efficiency (weight gain/milk consumed) were analysed using SAS (1987), while return to oestrus and milk protein data were analysed using Minitab (1994).

\section{Results and Discussion}

The average daily gains of the pregnant goats grazing Leucaena-grass pasture were significantly $(\mathrm{P}<0.05)$ higher than their counterparts grazing veld. Kids from does grazing Leucaena-grass pasture tended to be heavier $(\mathrm{P}$ $>0.05)$ at birth than their counterparts on veld grazing. Does that previously grazed Leucaena-grass pasture returned earlier to oestrus than their counterparts on veld grazing, but the differences were not significant (Table 1). Kid live weight gain and milk efficiency were not significantly influenced by the lactation diets (Table 1). Weights at weaning of does from the Leucaena group fed 10\% molasses concentrate and does from the veld group fed $0 \%$ molasses concentrate differed $(\mathrm{P}<0.05$; Table 1). Although milk yield from the Leucaena group was not significantly different from the veld group, peak lactation occurred earlier with $10 \%$ molasses than with $0 \%$ molasses (Figure 1). Milk protein contents and milk efficiency were independent of diet and stage of lactation.

Table 1 Return to oestrus, milk efficiency, live weight gains of kids and weaning weights of dams

\begin{tabular}{lllllc}
\hline & \multicolumn{2}{c}{ Leucaena-grass pasture } & \multicolumn{3}{c}{ Natural veld } \\
& $0 \%$ Molasses & $10 \%$ Molasses & $0 \%$ Molasses & $10 \%$ Molasses & sed \\
\hline Return to oestrus(days) & $27^{\mathrm{a}}$ & $23^{\mathrm{a}}$ & $35^{\mathrm{a}}$ & $52^{\mathrm{a}}$ & 16.14 \\
Milk efficiency $(\mathrm{g} / \mathrm{kg})$ & $141.36^{\mathrm{a}}$ & $109.32^{\mathrm{a}}$ & $134.41^{\mathrm{a}}$ & $124.08^{\mathrm{a}}$ & 27.73 \\
$\begin{array}{l}\text { Kids Live weight gain } \\
(\mathrm{g} / \mathrm{d})\end{array}$ & $143.18^{\mathrm{a}}$ & $140.7^{\mathrm{a}}$ & $142.55^{\mathrm{a}}$ & $126.84^{\mathrm{a}}$ & 20.21 \\
Dams weaning wt $(\mathrm{kg})$ & $35.56^{\mathrm{ab}}$ & $34.31^{\mathrm{a}}$ & $38.99^{\mathrm{b}}$ & $36.63^{\mathrm{ab}}$ & 1.48 \\
\hline
\end{tabular}

Row means with the same superscripts are not significantly different $(\mathrm{P}>0.05)$ 


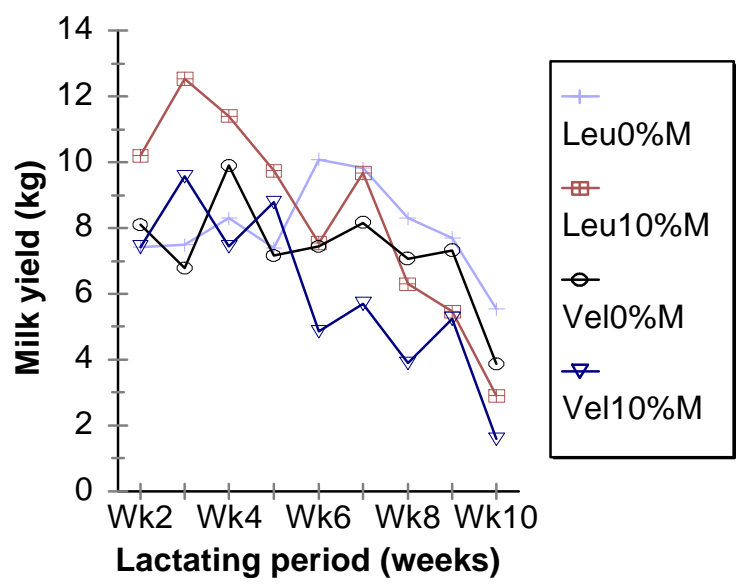

Figure 1 Milk production of lactating South African indigenous goats

Return to oestrus was not influenced by diets fed during and post gestation in agreement with the reports of Hamilton et al. (1971) that return to oestrus was unaffected by feeding Leucaena during gestation and of Mitchell et al. (1998) that return to oestrus was independent of lactation diets. Return to oestrus was also independent of weight at kidding, which contrasts with previous studies (Wright et al., 1987). The significantly $(\mathrm{P}<0.05)$ higher average daily gains of pregnant goats on Leucaena-grass pasture showed that the pasture was nutritionally superior to natural veld. Milk production increased with litter size (Raats et al., 1983) and dam weight at kidding. However, there was a reduction in milk efficiency and kids live weight gains with increased litter size (Ehoche \& Buvanendran, 1983) which perhaps suggests that additional milk resulting from multiple litters was not enough to support maximum growth of the kids. Milk protein content in this study accords with values (4.46\%) of Banda et al. (1990) from non-dairy goats in Malawi. Milk protein contents were independent of diets and stage of lactation (Ehoche \& Buvernendran, 1983).

\section{Conclusion}

Lactating does previously grazed on Leucaena-grass pasture returned to oestrus slightly earlier than their counterparts that grazed veld. The pre-weaning live weight gains of kids from the Leucaena group were marginally better than their counterparts in the veld group. Milk yields were higher in the Leucaena group than the veld group. Though these carry-over benefits were not statistically significant $(\mathrm{P}>0.05)$, marginal benefits seemed to be derived from feeding Leucaena leucocephala-grass pasture during gestation.

\section{References.}

AOAC, 1984. Official methods of Analysis. 15th Ed, Washington, DC, pp, 69-88.

Banda, J. W. et al., 1990. Proc. $1^{\text {st }}$ Conf. African Small Ruminant Res. Network, ILRAD. pp 461-483.

Duvel, G. H. \& Afful, D. B. 1994., Res. Rep. S. A. Inst. Agric. Ext., Univ. Pretoria.

Ehoche, O. W. \& Buvernendran, V., 1983. Wld. Rev. Anim. Prod. 19:19.

Hamilton, R. I. et al., 1971. Aust. J. Agric. Res., 22:681.

Hassan, A. et al., 1981. Wld. Anim. Rev., 28:65.

Nsahlai, I. V. et al., 1994. J. Sci. Food Agric., 69:235.

Mbayahaga, J. et al., 1998. Anim. Reprod. Sci., 51: 289.

Mitchell, L. M. et al., 1998. Anim. Sci., 67: 65.

Morris, C. D. \& du Toit, L. P., 1998. Trop. Grassl., 32:188

Mukasa-Mugerwa, E. et al., 1991. Anim. Reprod. Sci. 24: 73.

Raats, J. G.. et al., 1983. S. A. J. Anim. Sci, 13:240.

Wright, I. A. et al., 1987. Anim. Prod., 45: 395. 